\title{
UPAYA PEMBENTUKAN KARAKTER MELALUI SOCIAL AND EMOTIONAL LEARNING (SEL) PADA MATA PELAJARAN IPS DI SMP
}

\author{
Tiara Anggia Dewi \\ Program Studi Pendidikan Ekonomi Universitas Muhammadiyah Metro \\ tiara.anggia09@gmail.com
}

\begin{abstract}
Abstrak
Krisis karakter masih sulit dilepaskan dari perilaku masyarakat terutama generasi muda pada pendidikan dasar dan menengah. Untuk mencegah lebih parahnya krisis karakter tersebut, upaya pendidikan karakter bangsa melalui berbagai cara yang inovatif sangat penting untuk dikembangkan. Menumbuhkan jiwa yang berkarakter pada anak salah satunya adalah dengan pembelajaran sosial dan emosional (SEL) yang tidak terlepas dari perkembangan fisik, mental, dan emosi (Santrock, 2002). Pendidikan karakter sangat penting untuk disejajarkan kedudukannya dengan materi pokok pembelajaran IPS. Beberapa kebiasaan buruk dalam bersosial harus dapat dicegah dan diatasi sejak dini kepada peserta didik, sebab apabila tidak diupayakan untuk diminimalisir, maka hal tersebut akan mengakar dan sulit dihilangkan dari budaya generasi muda.
\end{abstract}

\section{Kata Kunci: Pendidikan Karakter, Pembelajaran Sosial dan Emosional (SEL), IPS}

\section{A. PENDAHULUAN}

Salah satu indikator kemajuan dan kualitas suatu bangsa adalah perkembangan moral generasi penerusnya (Likona, 1992). Permasalahan mengenai moral yang dimiliki anak-anak dan remaja di bangku sekolah sangat kompleks dan memprihatinkan. Dimulai dari kasus bullying, rendahnya sikap hormat pada guru seperti contoh kasus siswa dan orang tua yang menganiaya guru serta melaporkan guru ke polisi karena permasalahan-permasalahan tertentu. Hal ini menunjukkan bahwa rentannya perilaku menyimpang dari anak-anak maupun remaja akibat dari lingkungan psikologis dan sosiologis yang kurang mendukung perkembangan karakter anak.

Dalam menyelenggarakan pendidikan karakter tidak hanya sebatas bertumpu pada peran pemerintah melalui lembaga pendidikan formal yaitu sekolah, melainkan hal ini merupakan tanggung jawab semua pihak terutama lingkungan keluarga dan masyarakat. Peran dan fungsi ketiga lembaga pendidikan tersebut tidak hanya menghasilkan peserta didik yang cerdas dan terampil dari sisi akademis, tetapi juga mencerminkan proses pendidikan yang menjunjung nilainilai luhur agama dan budaya sebagai cerminan kepribadian bangsa yang mengakar dalam kehidupan masyarakat. Terkait dengan hal tersebut, secara teknis dibutuhkan penguatan pengelolaan pendidikan dengan pengembangan program-program yang berbasis pendidikan karakter.

Peraturan Menteri Pendidikan dan Kebudayaan, nomor 54 tahun 2013 tentang standar kompetensi lulusan pendidikan dasar dan menengah. Dinyatakan bahwa substansi karakter yang ada pada SKL 
SMP/MTs/SMPLB/Paket B meliputi menjalankan ajaran agama yang dianut sesuai dengan tahap perkembangan remaja; menunjukkan sikap percaya diri; mematuhi aturan-aturan sosial yang berlaku dalam lingkungan yang lebih luas; menghargai keberagaman agama, budaya, suku, ras, dan golongan sosial ekonomi dalam lingkup nasional, mencari dan menerapkan informasi dari lingkungan sekitar dan sumber-sumber lain secara logis, kritis, dan kreatif serta berkomunikasi dan berinteraksi secara efektif dan santun.

Sistem pendidikan nasional yang dimuat dalam UU 20 tahun 2003 dinyatakan bahwa Pendidikan Nasional Pendidikan nasional berfungsi mengembangkan kemampuan dan membentuk watak serta peradaban bangsa yang bermartabat dalam rangka mencerdaskan kehidupan bangsa, bertujuan untuk berkembangnya potensi peserta didik agar menjadi manusia yang beriman dan bertakwa kepada Tuhan Yang Maha Esa, berakhlak mulia, sehat, berilmu, cakap, kreatif, mandiri, dan menjadi warga negara yang demokratis serta bertanggung jawab.

Berdasarkan hal-hal diatas, secara formal upaya menyiapkan kurikulum yang mengarah pada pembentukan watak dan budi pekerti generasi muda memiliki landasan yuridis yang kuat. Namun hal tersebut masih belum dapat dirasakan efektivitasnya pada pembelajaran saat ini. Krisis karakter masih sulit dilepaskan dari perilaku masyarakat terutama generasi muda pada pendidikan dasar dan menengah. Untuk mencegah lebih parahnya krisis karakter tersebut, upaya pendidikan karakter bangsa melalui berbagai cara yang inovatif sangat penting untuk dikembangkan.

Dalam pemberian pendidikan karakter bangsa di sekolah, para pakar berbeda pendapat. Setidaknya ada tiga pendapat yang berkembang. Pertama, bahwa pendidikan karakter bangsa diberikan berdiri sendiri sebagai suatu mata pelajaran. Pendapat kedua, pendidikan karakter bangsa diberikan secara terintegrasi dalam mata pelajaran PKn, pendidikan agama, dan mata pelajaran lain yang relevan. Pendapat ketiga, pendidikan karakter bangsa terintegrasi ke dalam semua mata pelajaran.

Menumbuhkan jiwa yang berkarakter pada anak salah satunya adalah dengan pembelajaran sosial dan emosional (SEL) yang tidak terlepas dari perkembangan fisik, mental, dan emosi (Santrock, 2002). Perilaku sosial emosional yang positif atau social and emotional learning anak dapat ditumbuhkan melalui pendidikan formal dan informal yang dapat dirancang dan diintegrasikan dalam skenario pembelajaran.

IPS merupakan satu kajian dari berbagai disiplin ilmu, yang tidak hanya ilmu-ilmu sosial, akan tetapi juga ilmuilmu lainnya yang berkenaan dengan kehidupan manusia. Hal yang dikaji adalah tema-tema yang berkaitan dengan kehidupan manusia. Tema yang dikaji, adalah fenomena-fenomena yang terjadi di masyarakat baik masa lalu, masa sekarang, dan kecenderungannya di masamasa mendatang. Fenomena yang sedang terjadi (current events) merupakan sumber materi IPS yang sangat menarik, dan sangat penting untuk dibahas. Tujuan utama dari pembelajaran IPS ini adalah 
untuk melatih para siswa menjadi warganegara yang mampu mengambil keputusan secara demokratis dan rasional yang dapat diterima oleh semua golongan yang ada di dalam masyarakat. Oleh karena itu, dibutuhkan konsep-konsep pendidikan karakter yang kuat di dalam pembelajaran yang berbasis ilmu sosial agar siswa dapat menempatkan diri sebagai warga negara yang baik.

Berdasarkan pemaparan di atas, maka penulis tertarik untuk mengkaji upaya pembentukan karakter melalui Social and Emotional Learning (SEL) pada mata pelajaran IPS di SMP.

\section{KAJIAN PUSTAKA}

\section{Pendidikan Karakter}

Dalam naskah Kebijakan Nasional Pembagunan Karakter Bangsa, diuraikan bahwa, ada beberapa alasan mendasar yang melatari pentingnya pembangunan karakter bangsa, baik secara filosofis, ideologis, normatif, historis maupun sosiokultural. Secara filosofis, pembangunan karakter bangsa merupakan sebuah kebutuhan asasi dalam proses berbangsa karena hanya bangsa yang memiliki karakter dan jati diri yang kuat yang akan survive sebagai suatu bangsa. Secara ideologis, pembangunan karakter merupakan upaya mengejawantahkan ideologi Pancasila dalam kehidupan berbangsa dan bernegara. Secara normatif, pembangunan karakter bangsa merupakan wujud nyata langkah mencapai tujuan bangsa yaitu melindungi segenap bangsa Indonesia dan seluruh tumpah darah Indonesia, memajukan kesejahteraan umum, mencerdaskan kehidupan bangsa, ikut melaksanakan ketertiban dunia berdasarkan kemerdekaan, perdamaian abadi, dan keadilan sosial. Secara historis, pembangunan karakter bangsa merupakan sebuah dinamika inti proses kebangsaan yang terjadi tanpa henti dalam kurung sejarah, baik pada zaman penjajahan maupun di zaman kemerdekaan. Secara kultural, pembangunan karakter bangsa merupakan suatu keharusan dari suatu bangsa yang multicultural.

Menurut Sudewo (2011:14) karakter didefinisikan oleh sebagai kumpulan sifat baik yang menjadi perilaku sehari-hari, sebagai kesadaran menjalankan peran, fungsi, dan tugasnya dalam mengemban amanah dan tanggung jawab. Pendidikan karakter adalah gerakan nasional untuk menciptakan sekolah yang membina generasi muda yang beretika, bertanggung jawab, dan peduli melalui pemodelan dan mengajarkan karakter baik dengan penekanan pada nilai universal yang kita setujui bersama. Kementerian Pendidikan dan Kebudayaan, melalui Kebijakan Nasional Pembangunan Karakter Bangsa, karakter merupakan nilai-nilai khas yang baik (tahu nilai kebaikan, mau berbuat baik, nyata berkehidupan baik, dan berdampak baik terhadap lingkungan) yang terpateri dalam diri dan terejawantahkan dalam perilaku. Karakter secara koheren memancar dari hasil olah pikir, olah hati, olah raga, serta olah rasa dan karsa seseorang atau sekelompok orang. Karakter merupakan ciri khas seseorang atau sekelompok orang yang mengandung nilai, kemampuan, kapasitas moral, dan ketegaran dalam menghadapi kesulitan dan tantangan.

Upaya pembangunan karakter bangsa semestinya dioptimalkan dan dijadikan sebagai perioritas utama, karena banyaknya fakta-fakta sosial yang buruk yang terjadi di mana-mana. Dintaranya, fenomena sikap anarkis, pemaksaan kehendak, konflik sosial, kerusuhan dan kekerasan, tawuran pelajar dan mahasiswa, 
pergaulan bebas disertai pornografi dan pornoaksi, kejahatan seks, kesenjangan sosial ekonomi, monopoli perdagangan dan konglomerasi, semakin rusaknya lingkungan alam, korupsi, dan seterusnya.

Fakta-fakta ini mengindikasikan adanya ancaman serius masa depan bangsa. Institusi pendidikan, terutama pendidikan formal, tergolong pihak yang bertanggungjawab atas fakta-fakta sosial yang digambarkan di atas. Karena institusi pendidikan formal merupakan wadah yang teroganisir untuk membimbing, mendidik, dan membelajarkan generasi bangsa. Ahmad Husen (2010:19) menyebutkan, sekolah atau perguruan tinggi memiliki pengaruh dan dampak terhadap karakter siswa atau mahasiswa, baik disengaja maupun tidak. Hal ini menjadi entry point untuk menyatakan bahwa sekolah atau kampus mempunyai tugas dan tanggungjawab untuk melakukan pendidikan moral dan pembentukan karakter.

\section{Pendekatan Social-Emotional Learning(SEL)}

Pembelajaran sosial-emosional (SEL) adalah proses untuk membantu siswa mengembangkan pengetahuan, pemahaman dan keterampilan yang mendukung pembelajaran, perilaku positif, dan hubungan sosial yang konstruktif. SEL adalah sebuah pendekatan yang mengajarkan siswa untuk mengenali, mengatur, dan mengekspresikan aspek sosial dan emosional dari kehidupan siswa, sehingga siswa dapat belajar hidup dengan sukses di dunia dan mampu mengelola tugas-tugas kehidupan dengan baik (Nucci, 2008).

Program SEL yang bertujuan untuk mengembangkan lima kompetensi inti sosial-emosional terdiri dari:
1) Kesadaran diri (self-awareness): mengidentifikasi dan mengenali emosi, mengakui kepentingan pribadi dan kekuatan diri, serta mempertahankan rasa percaya diri

2) Pengelolaan diri (self-management): mengatur emosi untuk mengatasi stres, mampu mengontrol dan memotivasi diri untuk dapat mengatasi hambatan, pengaturan dan pemantauan kemajuan menuju pencapaian tujuan-tujuan pribadi dan akademik; mampu mengekspresikan emosi secara tepat

3) Kesadaran Sosial (social awareness):mampu berempati dengan orang lain, menghargai individu serta kelompok lain serta mengakui persamaan dan perbedaan.

4) Keterampilan menjalin hubungan (relationship skills):mampu membangun dan memelihara hubungan yang sehat dan bermanfaat berdasarkan kerjasama dan ketahanan terhadap tekanan sosial yang tidak pantas, mencegah, mengelola, dan menyelesaikan konflik interpersonal, dan mampu mencari bantuan bila diperlukan

5) Bertanggung jawab terhadap pengambilan keputusan (responsible decision-making):mampu mengambil keputusan berdasarkan pertimbangan semua faktor yang relevan, dengan standar etika yang berlaku, masalah keamanan, dan norma sosial, menanggung konsekuensi dari tindakan yang diambil, mengevaluasi, dan merefleksi diri.

Adapun pola implementasi SEL di sekolah bisa dilakukan dengan mengembangkan program pola hubungan siswa dengan guru, siswa dan orang tua untuk mengajarkan keterampilan, 
pengetahuan dan pemahaman terhadap siswa agar mampu membangun kompetensi sosial dan emosional. Memilih atau mengembangkan program yang sesuai untuk konteks sekolah.

Ada beberapa faktor yang harus dipertimbangkan dalam memilih program pembelajaran sosial-emosional untuk memastikan kesesuaian dengan konteks sekolah masing-masing individu. Suatu program pembelajaran sosial-emosional sekolah harus: (1) memberikan kesempatan bagi siswa untuk mengembangkan keterampilan sosial yang positif, pemahaman identitas dan konteks sosial; (2) berurutan secara alami dan membangun apa yang telah dipelajari siswa sebelumnya; (3) mencakup kompetensi inti lima sosial-emosional; (4) praktek-praktek pengajaran yang efektif berdasarkan bukti; dan (5) memungkinkan penilaian tentang kualitas belajar siswa yang akan dibuat.

Model pembelajaran sosial-emosional (SEL) dilakukan secara holistik untuk menumbuhkan kecerdasan emosional dan sosial.Pembelajaran holistik terjadi apabila kurikulum dapat menampilkan tema yang mendorong terjadinya eksplorasi atau kejadian-kejadian secara autentik dan alamiah. Dengan munculnya tema atau kejadian yang alami ini akan terjadi suatu proses pembelajaran yang bermakna dan materi yang dirancang akan saling terkait dengan berbagai bidang pengembangan yang ada dalam kurikulum. Pembelajaran holistik berlandaskan pada pendekatan inquiry, dimana anak dilibatkan dalam merencanakan, bereksplorasi dan berbagi gagasan. Anakanak didorong untuk berkolaborasi bersama teman-temannya dan belajar dengan "cara" mereka sendiri.Anak-anak diberdayakan sebagai si pembelajar dan mampu mengejar kebutuhan belajar mereka melalui tema-tema yang dirancang.

Sebuah pembelajaran sosialemosional (SEL) yang holistik hanya dapat dilakukan dengan baik apabila pembelajaran yang akan dilakukan alaminyata-dekat dengan diri anak. Guru yang melaksanakannya juga harus memiliki pemahaman konsep pembelajaran terpadu dengan baik. Selain itu juga dibutuhkan pula kreativitas guru dan sumber bahan ajar bervariasi serta pengalaman guru dalam berlatih membuat model-model pembelajaran yang tematisakan sangat menentukan kebermaknaan pembelajaran.

Tujuan model pembelajaran sosialemosional(SEL) yang holistik dan berkarakter, yaitu mengembangkan aspek fisik, emosi, sosial, kreativitas, spiritual dan intelektual siswa secara optimal. Selain itu juga bertujuan untuk membentuk manusia yang pembelajar sejati (lifelong learners).

Strategi pembelajarannya dilakukan dengan cara: (1) menerapkan metode belajar yang melibatkan partisipasi aktif murid, yaitu metode yang dapat meningkatkan motivasi murid karena seluruh dimensi manusia terlibat secara aktif dengan diberikan materi pelajaran yang kongkrit, bermakna, serta relevan dalam konteks kehidupannya (student active learning, contextual learning, inquiry-based learning, integrated learning); (2) menciptakan lingkungan belajar yang kondusif (conducive learning community), sehingga anak dapat belajar dengan efektif di dalam suasana yang memberikan rasa aman, penghargaan, tanpa ancaman, dan memberikan semangat; (3) memberikan pendidikan karakter secara eksplisit, sistematis, dan berkesinambungan dengan melibatkan 
aspek knowing the good, loving the good, and acting the good; (4) metode pengajaran yang memperhatikan keunikan masing-masing anak, yaitu menerapkan kurikulum yang melibatkan sembilan aspek kecerdasan manusia; dan (5) seluruh pendekatan di atas menerapkan prinsip-prinsip developmentally appropriate practices.

\section{Konsep Pembelajaran IPS}

Mata pelajaran IPS merupakan salah salah satu mata pelajaran yang ada di SMP. Terdapat beberapa definisi lain tentang IPS. Richard E. Gross, dkk (1978 : 3) menyatakan bahwa IPS adalah dasar pendidikan sosial, dalam mempersiapkan fungsi warga negara dengan bekal pengetahuan, keterampilan dan sikap yang memungkinkan masingmasing warga negara tersebut dapat tumbuh secara personal antara yang satu dengan yang lainnya secara baik, dan dalam berkontribusi pada kebudayaan yang akan datang.

Muriel Crosby dalam Leonard S. Kenworthy (1981:7) menyatakan bahwa IPS diidentifikasi sebagai studi yang memperhatikan pada bagaimana orang membangun kehidupan yang lebih baik bagi dirinya dan anggota keluarganya, bagaimana orang memecahkan masalahmasalah, bagaimana orang hidup bersama, bagaimana orang mengubah dan diubah oleh lingkungannya.

Berdasarkan beberapa definisi di atas dapat diartikan bahwa IPS merupakan pembelajaran yang berkaitan dengan kehidupan masing-masing individu sebagai makhluk sosial yang akan berkecimpung dalam kehidupan bermasyarakat dan bernegara.

Jack R. Fraenkel (1980:8) membagi tujuan IPS dalam empat katagori yaitu :
1. Pengetahuan

2. Keterampilan

3. Sikap

4. Nilai

Pengetahuan adalah kemahiran dan pemahaman terhadap sejumlah informasi dan ide-ide. Tujuan pengetahuan ini membantu siswa untuk belajar lebih banyak tentang dirinya dan fisiknya dan dunia sosial. Dalam praktek pembelajaran pengetahuan dapat berupa kegiatan siswa yang dikenalkan dengan konsep-konsep yang ada dalam ilmu-ilmu sosial misalnya demokrasi, relasi, kronologis, urbanisasi, migrasi, dan sebagainya. Keterampilan adalah pengembangan kemampuankemampuan tertentu sehingga digunakan pengetahuan yang diperolehnya. Beberapa keterampilan yang ada dalam IPS adalah :

a. Keterampilan berpikir yaitu kemampuan mendeskripsikan, mendefinisikan, mengklasifikasi, membuat hipotesis, membuat generalisasi, memprediksi, membandingkan dan mengkontraskan, dan melahirkan ide-ide baru.

b. Keterampilan akademik yaitu kemampuan membaca, menelaah, menulis, berbicara, mendengarkan, membaca dan meninterpretasi peta, membuat garis besar, membuat grafik dan membuat catatan.

c. Keterampilan penelitian yaitu mendefinisikan masalah, merumuskan suatu hipotesis, menemukan dan mengambil data yang berhubungan dengan masalah, menganalisis data, mengevaluasi hipotesis dan menarik kesimpulan, menerima, menolak atau memodifikasi hipotesis dengan tepat.

d. Keterampilan sosial yaitu kemampuan bekerjasama, memberikan kontribusi dalam tugas dan diskusi kelompok, 
mengerti tanda-tanda non-verbal yang disampaikan oleh orang lain, merespon dalam cara-cara menolong masalah yang lain, memberikan penguatan terhadap kelebihan orang lain, dan mempertunjukkan kepemimpinan yang tepat.

$\begin{array}{cr}\text { Sikap adalah } & \text { kemahiran, } \\ \text { mengembangkan dan menerima }\end{array}$ keyakinan-keyakinan, interes, pandanganpandangan, dan kecendrungan tertentu. Sedangkan nilai adalah kemahiran memegang sejumlah komitmen yang mendalam, mendukung ketika sesuatu dianggap penting dengan tindakan yang tepat.

\section{Pembentukan Karakter Pada Mata Pelajaran IPS}

Pendidikan karakter (sebagai bagian dari kurikulum) yang terintegrasikan dalam semua mata pelajaran, dalam proses pengembangannya haruslah mencakupi tiga dimensi yaitu kurikulum sebagai ide, kurikulum sebagai dokumen, dan kurikulum sebagai proses terhadap semua mata pelajaran yang dimuati pendidikan karakter bangsa (Hasan, 2000).

IPS merupakan mata pelajaran yang berkaitan dengan kehidupan individu baik sebagai warga negara maupun masyarakat. Individu yang diharapkan dalam IPS adalah individu yang saling berinteraksi antara yang satu dengan yang lainnya. Interaksi yang diharapkan adalah interaksi yang bisa membangun kehidupan yang lebih baik. Sebab secara sosiologis dan politis, apabila individu-individu tersebut memiliki yang baik, secara otomatis menunjukkan sebagai warga negara yang baik. Interaksi individu bukan hanya dengan sesama manusia, akan tetapi interaksi juga dilakukan dengan lingkungan baik lingkungan sosial maupun lingkungan alam. Dalam berinteraksi tersebut memungkinkan terjadinya masalah-masalah yang berdampak pada kehidupan manusia baik masalah yang berupa fenomena sosial maupun fenomena alam. Fenomena sosial, misalnya masalah urbanisasi yang berakibat terjadinya kepadatan penduduk di perkotaan. Fenomena alam, misalnya banjir yang dapat membawa pada krisis kemanusiaan.

IPS menuntut adanya pengetahuan, keterampilan dan sikap. Untuk menjadi warga negara yang baik, IPS memberikan bekal pengetahuan yang biasanya lebih menekankan pada aspek kognitif. Misalnya pengetahuan tentang apa yang menjadi penyebab terjadinya urbanisasi, apa yang menyebabkan terjadinya banjir, bagaimana cara-cara memghindari banjir, dan sebagainya. Keterampilan dan sikap lebih banyak menuntut terhadap apa yang dapat ditunjukkan oleh siswa dalam bentuk kinerja. Keterampilan dalam IPS memiliki arti yang lebih luas yang biasa disebut dengan keterampilan sosial. Keterampilan-keterampilan ini lebih banyak ditunjukkan dengan sikap ketika berinteraksi dengan individu-individu lain.Misalnya apakah individu menunjukkan sikap peduli ketika melihat tetangganya terkenan banjir, dan sebagainya.

Mengingat pentingnya pembelajaran bagi kehidupan siswa dalam bermasyarakat, oleh karena itu sisipan pendidikan karakter sangat penting untuk disejajarkan kedudukannya dengan materi pokok pembelajaran IPS. Pendidikan karakter dirasa sangat mendesak bagi bangsa Indonesia antara lain disebabkan karena bangsa kita telah lama memiliki kebiasaan-kebiasaan yang kurang mendukung untuk membangun bangsa yang berdaya saing tinggi. Beberapa 
kebiasaan buruk dalam bersosial yang dapat menghancurkan bangsa antara lain tidak mau membaca, jarang mendengarkan pendapat orang lain, nepotisme, suap menyuap, beragama secara sempit, lupa sejarah, provokatif, tawuran dll. Kebiasaan-kebiasaan tersebut harus dapat dicegah dan diatasi sejak dini kepada peserta didik, sebab apabila tidak diupayakan untuk diminimalisir, maka hal tersebut akan mengakar dan sulit dihilangkan dari budaya generasi muda.

IPS sebagai sebuah kajian memiliki kepentingan bagi pendidikan. Bruce Joyce dalam Leonard S. Kenworthy (1981 : 7) menyatakan ada tiga katagori dalam pendidikan yang merupakan karakteristik tujuan IPS yaitu :

1. Pendidikan kemanusiaan.

2. Pendidikan kewarganegaraan.

3. Pendidikan intelektual.

Pendidikan kemanusiaan memiliki arti bahwa IPS harus membantu anak memahami pengalamannya dan menemukan arti atau makna dalam kehidupannya. Dalam tujuan pertama ini terkandung unsur pendidikan nilai. Guru dapat menyajikan materi IPS dalam tujuan ini misalkan dalam materi krisis kemanusiaan yang disebabkan oleh terjadinya fenomena alam banjir. Banjir dapat menimbulkan korban. Bagaimana sikap yang harus dilakukan terhadap korban banjir. Pada tema ini bisa membicarakan hubungan antara fenomena sosial dan fenomena alam. Siswa dituntut memiliki sikap empati terhadap masalah kemanusiaan.

Pendidikan

kewarganegaraan mengandung arti bahwa siswa harus dipersiapkan untuk berpartisipasi secara efektif dalam dinamika kehidupan masyarakat. Siswa memiliki kesadaran untuk meningkatkan prestasinya sebagai bentuk tanggung jawab warga negara yang setia pada negara. Pendidikan nilai dalam tujuan ini lebih ditekankan pada kewarganegaraan. Materi yang disajikan lebih banyak tema yang berkaitan dengan kehidupan sebagai warga negara. Misalnya tema tentang etika berkendaraan di jalan raya. Bagaimana seorang warga negara yang baik menggunakan kendaraan, mentaati rambu-rambu lalu lintas, tidak ngebut di jalanan yang mengganggu ketentraman, dan sebagainya.

Pendidikan intelektual mengandung arti bahwa anak membutuhkan untuk memperoleh ide-ide yang analitis dan alat-alat untuk memecahkan masalah yang dikembangkan dari konsep-konsep ilmu sosial. Dalam memecahkan masalah anak akan dihadapkan pada upaya mengambil keputusan sendiri. Dengan peningkatan kematangan, anak harus belajar untuk menjawab pertanyaan dengan benar dan menguji ide-ide kritis dalam situasi sosial. Dalam pembelajaran ini, siswa diminta untuk berpikir kritis dalam mengkaji tema-tema yang diangkat dalam kehidupan nyata. Siswa diminta diminta untuk memberikan analisis dengan konsep-konsep ilmu sosial atau ilmu lainnya terhadap fakta yang terjadi. Misalkan terjadinya pengangguran, bagaimana pengangguran dilihat dari aspek sejarah, ekonomi, geografi, sosiologi dan yang lainnya.

Implementasi pendidikan karakter pada mata pelajaran IPS di sekolah seharusnya dirancang sedemikian rupa agar memperoleh hasil yang efektif. Beberapa langkah yang perlu dilakukan antara lain yaitu (1) integrasi pendidikan karakter ke dalam kegiatan pembelajaran di kelas, (2) dalam budaya sekolah 
dilakukan pembiasaan dalam kehidupan sehari-hari di satuan pendidikan, (3) integrasi ke dalam kegiatan Ekstrakurikuler Pramuka, Olahraga, Karya Tulis dsb, dan (4) penerapan pembiasaan kehidupan keseharian di rumah sama dengan satuan pendidikan.

\section{KESIMPULAN}

Dalam naskah Kebijakan Nasional Pembangunan Karakter Bangsa, diuraikan bahwa, ada beberapa alasan mendasar yang melatari pentingnya pembangunan karakter bangsa, baik secara filosofis, ideologis, normatif, historis maupun sosiokultural. Upaya pembangunan karakter bangsa semestinya dioptimalkan dan dijadikan sebagai perioritas utama, karena banyaknya fakta-fakta sosial yang buruk yang terjadi di mana-mana. Diantaranya, fenomena sikap anarkis, pemaksaan kehendak, konflik sosial, kerusuhan dan kekerasan, tawuran pelajar dan mahasiswa, pergaulan bebas disertai pornografi dan pornoaksi, kejahatan seks, kesenjangan sosial ekonomi, monopoli perdagangan dan konglomerasi, semakin rusaknya lingkungan alam, korupsi, dan seterusnya.

Implementasi pendidikan karakter pada mata pelajaran IPS di sekolah seharusnya dirancang sedemikian rupa agar memperoleh hasil yang efektif. Beberapa langkah yang perlu dilakukan antara lain yaitu (1) integrasi pendidikan karakter ke dalam kegiatan belajar mengajar (KBM) di kelas, (2) dalam budaya sekolah dilakukan pembiasaan dalam kehidupan sehari-hari di satuan pendidikan, (3) integrasi ke dalam kegiatan Ekstrakurikuler Pramuka, Olahraga, Karya Tulis dsb, dan (4) penerapan pembiasaan kehidupan keseharian di rumah sama dengan satuan pendidikan.

\section{DAFTAR PUSTAKA}

Ahmad Husen, dkk. 2010. Model Pendidikan Karakter Bangsa. Jakarta:UNY.

DPR RI dan Presiden RI. 2003. UndangUndang No. 20 tentang Sistem Pendidikan Nasional. Jakarta.

Hasan, S. Hamid. 2000. Pendekatan Multikultural untuk Penyempurnaan Kurikulum, Bandung: Remaja Rosdakarya.

Kemendiknas Republik Indonesia. 2010. Kebijakan Nasional Pembangunan Karakter Bangsa. Jakarta: Pusat Kurikulum Balitbang Kemendiknas.

Larry P.Nucci. 2008. Handbook of Moral and Character Education. New York and London: Routledge.

Likona, T. 1992. Educating For Character: How Our Schools Cant Teach Repect and responsibility. New York: Bantam Book.

R. Fraenkel, Jack. 1980. Helping Students Think Value Strategies for Teaching Social Studies. New Jersey: PrenticeHall.

Richard E. Gross, et.al. 1978. Social Studies For Our Times, New York: John Wiley \& Sons.

Santrock, J.W. 2002. Life-Span Development (Perkembangan Masa Hidup). Penerbit Erlangga: Jakarta. 
e-ISSN : 2442-4994 Vol.4. $\mathcal{N} 0.2$ (2016) 13-22

$p$-ISSN : $2337-4721$

S. Kenworthy, Leonard. 1981. Social Studies For The Eighties. Canada : John Wiley \& Sons.

Sudewo, Erie. 2011. Character Building: Menuju Indonesia Lebih Baik. Jakarta: Republika Penerbit. 